\title{
Influence of PGR's and Cultivars on Flower Yield and Economics of African Marigold under Chhattisgarh Plain
}

\author{
P. S. Markam ${ }^{1 *}$, Neeraj Shukla ${ }^{2}$ and Vikas Chandra ${ }^{3}$ \\ ${ }^{1}$ Department of Horticulture, College of Agriculture, I.G.K.V., Raipur 492012, \\ Chhattisgarh, India \\ ${ }^{2}$ Department of Horticulture College of Agriculture and Research Station I.G.K.V., \\ Kanker, 494334, Chhattisgarh, India \\ ${ }^{3}$ Department of Agriculture, Government of Uttar Pradesh, Azamgarh 276304, \\ Uttar Pradesh, India \\ *Corresponding author
}

\section{A B S T R A C T}

\begin{tabular}{|l|}
\hline Ke y w o r d s \\
$\begin{array}{l}\text { Tagetes erecta, } \\
\mathrm{GA}_{3} \text {, Cycocel, } \\
\text { Growth, Benefit: } \\
\text { cost ratio }\end{array}$ \\
\hline Article Info \\
$\begin{array}{l}\text { Accepted: } \\
\text { 10 July } 2020 \\
\text { Available Online: } \\
10 \text { August } 2020\end{array}$ \\
\hline \hline
\end{tabular}

A field trail was conducted to study the effect of different levels of growth promoters and retardants on growth and flower yield of different cultivars of African marigold. Two PGR's namely Gibberellins $\left(\mathrm{GA}_{3}\right)$ and Cycocel $(\mathrm{CCC})$ were taken as growth promoter and growth retardant, respectively. Two cultivars namely Pusa Narangi Gainda and Pusa Basanti Gainda were taken to evaluate their suitability in Chhattisgarh. The result indicated that the growth and flower yield were significantly influenced by different plant growth regulators and cultivars. The maximum plant height was recorded with $c v$. Pusa Basanti Gainda as compared to $c v$. Pusa Narangi Gainda. While, maximum number of primary and secondary branches was recorded with $c v .\left(\mathrm{V}_{1}\right)$ Pusa Narangi Gainda. Among the growth regulators treatments $\mathrm{GA}_{3} 300 \mathrm{ppm}(25 \mathrm{DAT})+\mathrm{GA}_{3} 300 \mathrm{ppm}(45 \mathrm{DAT})$ recorded maximum plant height. However, maximum number of primary and secondary branches, number of flowers, fresh weight of flowers per plant and flower yield $\mathrm{ha}^{-1}$ was noticed with treatment $\mathrm{GA}_{3} 300 \mathrm{ppm}(25 \mathrm{DAT})+\mathrm{CCC} 1500 \mathrm{ppm}(45 \mathrm{DAT})$. The pooled analysis of two year data also indicated that the general cost of marigold cultivation was (59750.00 Rs. ha ${ }^{-1}$ ) per hectare including labour cost, cost of various inputs and over head costs. The highest gross returns (236620.00 Rs. $\left.\mathrm{ha}^{-1}\right)$, net returns (159595.00 Rs. ha $\left.{ }^{-1}\right)$ and highest benefit: cost ratio (3.20) was found in the treatment $\left(\mathrm{GA}_{3} 300 \mathrm{ppm}+\mathrm{CCC}\right.$ $1500 \mathrm{ppm})$ whereas the lowest (151020.00 Rs. ha $\left.{ }^{-1}\right)$ was observed in control.

\section{Introduction}

African marigold (Tagetes erecta L.) is one of the important commercial flower belongs to the family asteraceae. It is a native of Central and South America, especially Mexico, from where it spread to different parts of the world during early parts of the $16^{\text {th }}$ century (Kaplan, 1960). Chhattisgarh state has covered an area of 5131.00 million hectare with an annual production of 40448.00 metric tonnes (Anonymous, 1). African marigold is popular 
throughout the world because of wide spectrum of attractive colours, shape and good keeping quality which has attracted the attention of flower growers. They are extensively used as loose flower, potted plant and also as a bedding plant. Loose flowers are in great demand for garland making as well as in religious and social functions. Globular shaped flowers with long stalks are used for cut flower purposes. The plant is very useful as both the leaves and the flowers are equally important from medicinal point of view. The paste and extracts from plant are used as cure for boils, ear ache, eye disease and ulcers. The productivity can be enhanced in Chhattisgarh by the incorporating suitable varieties and use of PGR's, which can prove to be better option for the farmers of Chhattisgarh. In recent year, use of plant growth regulators is being increased to manipulate the growth, flowering and yield of many ornamental plants. Gibberellic acid and Cycocel are very important plant growth regulators and are widely used in horticulture. Therefore, the combination of both growth promoter and growth retardant at their right level and their right stage of crop is highly desired. The application of $\mathrm{GA}_{3}$ regulation of growth itself is involved with both cell division and cell enlargements without cell division reported by (Haber and Leopold 1960). The application of cycocel retarded stem elongation by preventing cell division in the sub-apical meristem, usually without similarly affecting the apical meristem reported by (Sachs et al., 1960). Gibbrellin activates the vertical growth of plant by sensitizing the apical meristem, while cycocel enforce stop the vertical growth consequently induces the lateral or horizontal growth. Use of plant growth regulators is being increased to manipulate the growth, flowering and yield of many ornamental plants. Thus, keeping in view the potentialities of growth regulators like $\mathrm{GA}_{3}, \mathrm{CCC}$ the present study was undertaken to find out the suitable concentration for better flowering and yield of African marigold.

\section{Materials and Methods}

The present experiment was carried out during two rabi seasons of the years 2014-15 and 2015-16 at Agriculture Farm Singarbhat, College of Agriculture and Research station, Kanker Chhattisgarh. The Kanker district is situated in the central part of Chhattisgarh and lies between $20^{\circ} 14^{\prime} \mathrm{N}$ latitude and $81^{\circ} 30^{\prime} \mathrm{E}$ longitudes at an altitude of $417 \mathrm{~m}$ above mean sea level. The Chhattisgarh state is situated near equator and lies under tropical climate. The maximum temperature of this region may reach as high as $42{ }^{0} \mathrm{C}$ during summer and the minimum may fall to $6{ }^{0} \mathrm{C}$ during winter. The Kanker districts enjoys both the agro-climatic zone namely Bastar plateau and Chhattisgarh plains. The experiment was laid out in Randomized Block Design (Factorial) with three replications comprising fourteen treatment combinations of seven levels of PGR's viz., $\mathrm{GA}_{3} 200 \mathrm{ppm}$ at $25 \mathrm{DAT}+\mathrm{GA}_{3}$ $200 \mathrm{ppm}$ at $45 \mathrm{DAT}\left(\mathrm{P}_{1}\right), \mathrm{GA}_{3} 300 \mathrm{ppm}$ at 25 $\mathrm{DAT}+\mathrm{GA}_{3} 300 \mathrm{ppm}$ at $45 \mathrm{DAT}\left(\mathrm{P}_{2}\right), \mathrm{GA}_{3}$ $200 \mathrm{ppm}$ at $25 \mathrm{DAT}+\mathrm{CCC} 1000 \mathrm{ppm}$ at 45 $\operatorname{DAT}\left(\mathrm{P}_{3}\right), \mathrm{GA}_{3} 300 \mathrm{ppm}$ at $25 \mathrm{DAT}+\mathrm{CCC}$ $1000 \mathrm{ppm}$ at $45 \mathrm{DAT}\left(\mathrm{P}_{4}\right), \mathrm{GA}_{3} 200 \mathrm{ppm}$ at 25 $\mathrm{DAT}+\mathrm{CCC} 1500 \mathrm{ppm}$ at $45 \mathrm{DAT}\left(\mathrm{P}_{5}\right), \mathrm{GA}_{3}$ $300 \mathrm{ppm}$ at $25 \mathrm{DAT}+\mathrm{CCC} 1500 \mathrm{ppm}$ at 45 DAT $\left(\mathrm{P}_{6}\right)$ along with distill water spray $\left(\mathrm{P}_{7}\right)$ and two varieties viz., Pusa Narangi Gainda and Pusa Basanti Gainda of African marigold were taken. Seedlings of African marigold were raised in the beds of the nursery. The beds were dug and prepared thoroughly to make the soil pulverized. Four weeks old seedlings were planted in the experimental field. The operation of transplanting was carried out in the afternoon followed by a light irrigation which allow for proper establishment of seedlings. Desired quantities of the $\mathrm{GA}_{3}$ were first dissolved in few drops of alcohol $\left(\mathrm{C}_{2} \mathrm{H}_{5} \mathrm{OH}\right)$ and then volume was 
made up to $500 \mathrm{ml}$ of distilled water to make the proper concentrations of $\mathrm{GA}_{3}$. Cycocel was dissolved in required amount of distilled water for preparation of stock solution and then diluted before spraying. The spraying was done in the morning hours with the help of hand sprayer. Two time periods of crop growth were chosen for spraying of PGR's i.e., first at $25 \mathrm{DAT}$ and at $45 \mathrm{DAT}$. Observations were recorded at 30, 60 and 90 days after transplanting. The various growth parameters like height of plant and number of branches per plant were recorded for observation. The yield parameters like number of flowers per plant, fresh weight of flower and flower yield were also recorded.

\section{Results and Discussion}

\section{Influence of Varieties}

The data presented in (Table 1) show that the varieties of African marigold had significant effect on growth characters. The maximum plant height was recorded with $c v$. Pusa Basanti Gainda $\left(\mathrm{V}_{2}\right)$ as $(96.44 \mathrm{~cm})$ and $(94.39$ $\mathrm{cm}$ ) in both the year respectively. While, minimum plant height was measured under $c v$. Pusa Narangi Gainda $\left(\mathrm{V}_{2}\right)$. The pooled mean data revealed that maximum number of primary and secondary branches (15.07 and 44.42 respectively), number of flowers (60.68), fresh weight of flower $(0.28 \mathrm{~kg})$ per plant and flower yield (141.44 q ha $\left.{ }^{-1}\right)$ were recorded under $c v$. Pusa Narangi Gainda $\left(\mathrm{V}_{1}\right)$ whereas, it was found minimum under $V_{2}$ (Pusa Basanti Gainda). The maximum plant height followed due to positive response to height by the variety. The variation in plant height, number of primary and secondary branches, number of flowers, fresh weight of flower per plant and flower yield between African marigold varieties might be due to congenial environment to express the dominant genes in the genotypes and different genetic makeup of different varieties. Similar observations are conformity with the (Bhanu Pratap et al., 1999; Sreekala et al., 2002; Rao et al., 2005) in African marigold. Similar findings were also reported by (Namita et al., 2008) in French marigold and (Narsude et al., 2010) in African marigold. The present findings indicate that the application of $\mathrm{GA}_{3}+$ $\mathrm{CCC}$ at various levels had highly significant influence on number of primary and secondary branches per plant in African marigold. The maximum number of primary and secondary branches i.e. 15.71 and 45.44 respectively, were recorded under the PGR's combination of $\mathrm{GA}_{3} 300$ ppm (25 DAT) + CCC 1500 ppm (45 DAT) whereas, minimum was recorded in distilled water (Table 1). The increase in number of branches plant ${ }^{-1}$ with cycocel treatment might be due to reduction in shoot growth and increase in number of leaves per plant. Similar results were also reported by (Bhattacharjee and Das 1979) in gypsophila and (Biswas, 1981) in African marigold.

\section{Flowering and yield parameters}

$\mathrm{GA}_{3}$ and $\mathrm{CCC}$ application at various levels had highly significant effect on the fresh weight of flowers plant ${ }^{-1}$ and flower yield quintal $\mathrm{ha}^{-1}$ in African marigold (Table 2). Maximum fresh weight of flowers and flower yield was recorded with the treatment $\mathrm{GA}_{3}$ 300 ppm + CCC 1500 ppm i.e. $0.298 \mathrm{~kg}$ plant $^{-}$ ${ }^{1}$ and $147.39 \mathrm{q} \mathrm{ha}^{-1}$ as compared with $0.222 \mathrm{~kg}$ plant $^{-1}$ and $108.83 \mathrm{q} \mathrm{ha}^{-1}$ for control, respectively.

The increase in fresh weight of flowers and flower yield with $\mathrm{GA}_{3}$ and CCC spray may be due to more number of branches and leaves per plant and also increase the number of flowers plant ${ }^{-1}$, thus ultimately increased the flower yield plant. Similar results were also reported by (Girwani et al., 1990; Narayana and Jayanthi 1993) in African marigold. Similar findings were also reported by 
(Aswath et al., 1993) in China aster. The combined application of $\mathrm{GA}_{3}(25$ DAT) and CCC (45 DAT) at the rate of $300 \mathrm{ppm}$ and CCC $1500 \mathrm{ppm}$ respectively enhanced the lateral vegetative as well as yield attributes.

Therefore combined use of $\mathrm{GA}_{3}$ and $\mathrm{CCC}$ is better option over the sole application of $\mathrm{GA}_{3}$ and CCC. Experimental findings also show that the number of flowers per plant in African marigold was significantly affected by $\mathrm{GA}_{3}+\mathrm{CCC}$ applications at various concentrations, without affecting the initiation of flower bud as well as commencement of flowering. Maximum number of flowers per plant was recorded with the treatment $\mathrm{GA}_{3}$ $300 \mathrm{ppm}$ + CCC 1500 ppm i.e. $63.32\left(\mathrm{P}_{6}\right)$ flowers per plant as compared with 46.82 flowers per plant for control (Table 2).

The increase in number of flowers plant ${ }^{-1}$ with the application of $\mathrm{GA}_{3}$ and cycocel may be due to increased number of branches and mobilization of biomass to flowers from sources. Similar results were also reported by (Yadav, 1997) in African marigold.

Table.1 Effect of varieties and plant growth regulators on Number of flowers and flower yield of African marigold

\begin{tabular}{|c|c|c|c|c|c|c|}
\hline Treatments & \multicolumn{3}{|c|}{ Number of flowers per plant } & \multicolumn{3}{|c|}{ Flower yield (q/ha) } \\
\hline Varieties & 2014-15 & 2015-16 & Pooled Mean & 2014-15 & 2015-16 & Pooled Mean \\
\hline Pusa Narangi Gainda - $V_{1}$ & 62.31 & 59.05 & 60.68 & 146.73 & 136.16 & 141.44 \\
\hline Pusa Basanti Gainda $-V_{2}$ & 50.49 & 47.24 & 48.87 & 127.83 & 116.56 & 122.19 \\
\hline SEm SEm \pm & 1.462 & 1.472 & 1.108 & 1.706 & 2.116 & 1.212 \\
\hline $\mathrm{CD}(\mathrm{p}=0.05)$ & 4.274 & 4.303 & 3.238 & 4.986 & 6.184 & 3.544 \\
\hline PGR & & & & & & \\
\hline $\begin{array}{c}P_{1^{-}} \mathrm{GA}_{3} 200 \mathrm{ppm}(25 \mathrm{DAT})+ \\
\mathrm{GA}_{3} 200 \mathrm{ppm}(45 \mathrm{DAT})\end{array}$ & 50.54 & 48.23 & 49.38 & 130.45 & 118.44 & 124.45 \\
\hline $\begin{array}{c}P_{2}-G_{3} 300 \text { ppm }(25 \text { DAT })+ \\
\text { GA }_{3} 300 \text { ppm (45 DAT) }\end{array}$ & 54.02 & 50.66 & 52.34 & 132.58 & 121.90 & 127.24 \\
\hline $\begin{array}{r}P_{3}-G_{3} 200 \text { ppm (25 DAT) + } \\
\text { CCC } 1000 \text { ppm (45 DAT) }\end{array}$ & 55.52 & 52.76 & 54.14 & 137.93 & 127.81 & 132.87 \\
\hline $\begin{array}{r}P_{4}-G A_{3} 300 \text { ppm (25 DAT) }+ \\
\text { CCC } 1000 \text { ppm (45 DAT })\end{array}$ & 59.48 & 56.00 & 57.74 & 144.45 & 132.70 & 138.58 \\
\hline $\begin{array}{r}P_{5}-G_{3} 200 \text { ppm (25 DAT) }+ \\
\text { CCC } 1500 \text { ppm (45 DAT) }\end{array}$ & 62.31 & 57.06 & 59.69 & 151.10 & 135.63 & 143.37 \\
\hline $\begin{array}{c}P_{6}-G_{3} 300 \text { ppm }(25 \text { DAT })+ \\
\text { CCC } 1500 \text { ppm }(45 \text { DAT })\end{array}$ & 66.57 & 60.06 & 63.32 & 154.17 & 140.62 & 147.39 \\
\hline $\mathbf{P}_{7}$ - Distilled water & 46.37 & 47.26 & 46.82 & 110.27 & 107.40 & 108.83 \\
\hline SEm \pm & 2.735 & 2.754 & 2.073 & 3.191 & 3.958 & 2.268 \\
\hline $\begin{array}{l}\qquad \mathrm{CD}(\mathrm{p}=\mathbf{0 . 0 5}) \\
\text { Treatment combinations } \\
(\text { PGR X V) CD }(p=0.05)\end{array}$ & $\begin{array}{l}7.996 \\
\text { NS }\end{array}$ & $\begin{array}{l}8.049 \\
\text { NS }\end{array}$ & $\begin{array}{l}6.059 \\
\text { NS }\end{array}$ & $\begin{array}{l}9.329 \\
\text { NS }\end{array}$ & $\begin{array}{c}11.596 \\
\text { NS }\end{array}$ & $\begin{array}{c}6.630 \\
\text { NS }\end{array}$ \\
\hline
\end{tabular}


Table.2 Effect of varieties and plant growth regulators on Economics (Rs. ha ${ }^{-1}$ ) of African marigold

\begin{tabular}{|c|c|c|c|c|c|}
\hline Treatment Combinations ( $\mathbf{G} \times \mathbf{V})$ & $\begin{array}{l}\text { Total Cost } \\
\quad(\text { Rs. })\end{array}$ & $\begin{array}{l}\text { Yield } \\
\text { (q/ha) }\end{array}$ & $\begin{array}{c}\text { Gross } \\
\text { return } \\
\text { (Rs./ha) }\end{array}$ & $\begin{array}{l}\text { Net return } \\
\quad(\text { Rs. })\end{array}$ & $\begin{array}{l}\text { Benefit: } \\
\text { cost ration }\end{array}$ \\
\hline $\begin{array}{l}\mathrm{G}_{1} \mathrm{~V}_{1}-\mathrm{GA}_{3} 200 \mathrm{ppm}(25 \mathrm{DAT}) \\
+\mathrm{GA}_{3} 200 \mathrm{ppm}(45 \mathrm{DAT})\end{array}$ & 79750.00 & 133.26 & 199890 & 120140 & 2.50 \\
\hline $\begin{array}{l}\mathrm{G}_{1} \mathrm{~V}_{2^{-}} \mathrm{GA}_{3} 200 \mathrm{ppm}(25 \mathrm{DAT}) \\
+\mathrm{GA}_{3} 200 \text { ppm (45 DAT) }\end{array}$ & 79750.00 & 115.63 & 173445 & 93695 & 2.28 \\
\hline $\begin{array}{l}\mathrm{G}_{2} \mathrm{~V}_{1^{-}} \mathrm{GA}_{3} 300 \mathrm{ppm}(25 \mathrm{DAT}) \\
+\mathrm{GA}_{3} 300 \mathrm{ppm}(45 \mathrm{DAT})\end{array}$ & 89750.00 & 136.90 & 205350 & 115600 & 1.96 \\
\hline $\begin{array}{l}\mathrm{G}_{2} \mathrm{~V}_{2^{-}} \mathrm{GA}_{3} 300 \mathrm{ppm}(25 \mathrm{DAT}) \\
\quad+\mathrm{GA}_{3} 300 \mathrm{ppm}(45 \mathrm{DAT})\end{array}$ & 389750.00 & 117.58 & 176370 & 86620 & 3.03 \\
\hline $\begin{array}{l}\mathrm{G}_{3} \mathrm{~V}_{1}-\mathrm{GA}_{3} 200 \mathrm{ppm}(25 \mathrm{DAT}) \\
\text { +CCC } 1000 \text { ppm (45 DAT) }\end{array}$ & 71000.00 & 143.42 & 215130 & 144130 & 2.58 \\
\hline $\begin{array}{l}\mathrm{G}_{3} V_{2^{-}} \mathrm{GA}_{3} 200 \mathrm{ppm}(25 \mathrm{DAT}) \\
+\mathrm{CCC} 1000 \mathrm{ppm}(45 \mathrm{DAT})\end{array}$ & 71000.00 & 122.32 & 183480 & 112480 & 2.94 \\
\hline $\begin{array}{l}\mathrm{G}_{4} \mathrm{~V}_{1^{-}} \mathrm{GA}_{3} 300 \mathrm{ppm}(25 \mathrm{DAT}) \\
+\mathrm{CCC} 1000 \mathrm{ppm}(45 \mathrm{DAT})\end{array}$ & 76000.00 & 149.19 & 223785 & 147785 & 2.52 \\
\hline $\begin{array}{l}\mathrm{G}_{4} V_{2^{-}} \mathrm{GA}_{3} 300 \mathrm{ppm}(25 \mathrm{DAT}) \\
+\mathrm{CCC} 1000 \mathrm{ppm}(45 \mathrm{DAT})\end{array}$ & 76000.00 & 127.26 & 191940 & 115940 & 3.20 \\
\hline $\begin{array}{l}\mathrm{G}_{5} \mathrm{~V}_{1^{-}} \mathrm{GA}_{3} 200 \text { ppm (25 DAT) } \\
\text { +CCC } 1500 \text { ppm (45 DAT) }\end{array}$ & 71625.00 & 152.87 & 229305 & 157680 & 2.80 \\
\hline $\begin{array}{l}\mathrm{G}_{5} \mathrm{~V}_{2^{-}} \mathrm{GA}_{3} 200 \mathrm{ppm}(25 \mathrm{DAT}) \\
\text { +CCC } 1500 \text { ppm (45 DAT) }\end{array}$ & 71625.00 & 133.86 & 200790 & 129195 & 3.08 \\
\hline $\begin{array}{l}\mathrm{G}_{6} \mathrm{~V}_{1}-\mathrm{GA}_{3} 300 \mathrm{ppm}(25 \mathrm{DAT})+ \\
\mathrm{CCC} 1500 \mathrm{ppm}(45 \mathrm{DAT})\end{array}$ & 76625.00 & 157.48 & 236220 & 159595 & 2.68 \\
\hline $\begin{array}{c}\mathrm{G}_{6} \mathrm{~V}_{2}-\mathrm{GA}_{3} 300 \mathrm{ppm}(25 \mathrm{DAT})+ \\
\mathrm{CCC} 1500 \mathrm{ppm}(45 \mathrm{DAT})\end{array}$ & 76625.00 & 137.31 & 205965 & 129340 & 2.93 \\
\hline$G_{7}$ V1- Distilled water & 59750.00 & 116.99 & 175485 & 115735 & 2.93 \\
\hline G7V2- Distilled water $_{7}$ & 59750 & 100.68 & 151020 & 91270 & 2.52 \\
\hline
\end{tabular}

*Selling Price of marigold - Rs. 15/kg

The interaction between varieties and growth regulators did not show any significant results for vegetative characters and flowering and yield components. This may be because of these treatments acted independently rather than synergistically. Similar results were also reported by (Singh et al., 1991; Tomar et al., 2004; and Sunitha et al., 2007) in African marigold. Thus, it can be concluded that varieties and foliar spray of plant growth regulators $\left(\mathrm{GA}_{3}\right.$ and $\left.\mathrm{CCC}\right)$ jointly or separately gave higher flower yield in African marigold.

\section{Economics}

An inquisition of the pooled data in Table 2 also depicted the general cost of marigold cultivation was $\left(59750.00\right.$ Rs. ha $\left.{ }^{-1}\right)$ per hectare including labour cost, cost of various inputs and over head costs. The highest gross return of (236220.00 Rs. ha $\left.{ }^{-1}\right)$ was found in 
the treatment $\left(\mathrm{GA}_{3} 300 \mathrm{ppm}+\mathrm{CCC} 1500 \mathrm{ppm}\right)$ followed by $\left(\mathrm{GA}_{3} 200 \mathrm{ppm}+\mathrm{CCC} 1500 \mathrm{ppm}\right)$ of (229305.00 Rs. ha $\left.{ }^{-1}\right)$ whereas the lowest (151020.00 Rs. ha ${ }^{-1}$ ) was observed in control. The highest benefit: cost ratio (3.20) was calculated in $\mathrm{GA}_{3}$ 200ppm + CCC 1500ppm followed by $\mathrm{GA}_{3} 300 \mathrm{ppm}+\mathrm{CCC} 1500 \mathrm{ppm}$. As per the economic point of view the $\mathrm{GA}_{3}$ $200 \mathrm{ppm}+\mathrm{CCC}$ 1500ppm gained more benefit: cost ratio, thus this combination was more better for high return from the cultivation of marigold. This might be due to the fact that the foliar application of growth regulators and varietal response might have improved the yield and quality of African marigold flower. Similar findings are noticed by (Naik et al., 2005) in African marigold.

\section{Acknowledgement}

We are obliged to the Department of Horticulture, College of Agriculture and Research Station (Indira Gandhi Krishi Vishwavidyalaya) Kanker Chhattisgarh, India for the cooperation during the research work and encouragement given during course of study.

\section{References}

Anonymous. 2018. Area and production of fruit crops, Directorate of Horticulture, Raipur. Websitehttp://agridept.cg.gov.in/agriculture/hort iculture.htm.

Aswath, S., Narayana, G.J.V. and Ananda, M.G.M. 1994. Effect of growth retardants on growth, flowering and nutrient contents in China aster (Callistephus chinensis L.) cv. Powder puff mixed. Journal of Ornamental Horticulture. 2: 9-13.

Bhanu, P., Tiwari, G.N. and Mishra, L.N. 1999. Correlation studies in marigold. Journal of Ornamental Horticulture. 2(2): 84-88.
Bhattacharjee, S.K. and Das, P. 1979. Studies on the effect of growth retardants and their interaction with auxin and gibberellins in some herbaceous ornamentals. Orissa Journal of Horticulture. 7: 19-27.

Biswas, S. 1981. Studies on the comparative effect of cycocel and ethrel on growth and flowering of some ornamental plants, West Bengal, India. Ph.D. Thesis, Calcutta University, Calcutta, India.

Girwani, A.R., Srihari, B. and Chandrashekhar, R. 1990. Response of marigold (Tagetes erecta L.) to growth regulators and zinc. Indian Journal of Agricultural. Science. 60 (3): 220-222.

Haber, A.H. and Leopold, H.J. 1960. Effects of gibberellins and gamma irradiated wheat. American Journal of Botany. 47: 140-144.

Kaplan, L. 1960. Historical and ethnobotanical aspects of domestication in Tagetes erecta. Economy Botany. 14: 200-202.

Naik, H.B., Patil, A.A., Patil, V.S. and Basavaraj, N. 2005. Stability analysis in African marigold (Tagetes erecta L.) genotypes for growth and flower yield. Karnataka Journal of Agricultural Science. 18(3): 758-763.

Narayana, G.J.V. and Jayanthi, R. 1993. Studies on effect of spacing and season of planting on growth and yield of marigold (Tegetes erecta L.). Prog. Hort. 23(4): 114-118.

Narsude, P.B., Kadam, A.S. and Patil, V.K. 2010. Studies on the growth and yield attributes of different African marigold (Tagetes erecta L.) genotypes under Marathwada condition. Asian Journal of Horticulture. 5(2): 284-286.

Namita, K.P., Singh, D.V., Raju, S., Prasad, K.V. and Bhardwaj, C. 2008. Studies on genetic variability, heritability and genetic Advancein French marigold 
(Tagetes patula) genotypes. Journal of Ornamental Horticulture. 12(1): 30-34.

Rao, C.C., Gaud, P., Veerana, Reddy., Mala, K. and Padmaja, G. 2005. Screening of African marigold (Tagetes erecta L.) cultivars for flower yield and carotenoid pigment. Indian Journal of Horticulture. 62(3): 276-79.

Sachs, R.M., Long, A., Bretz, C.F. and Roach, J. 1960. Shoot histogenesis, subapical merismetic activity in calnescent plant and the action of gibberellic acid and AMO 1618. Americal Journal of Botany. 47: 260-266.

Singh, M.P., Singh, R.P. and Singh, G.N. 1991. Effect of $\mathrm{GA}_{3}$ and Ethrel on the growth and fowering of African marigold (Tagetes erecta L.). Haryana Journal of Horticultural Sciences. 20: 81-84.

Sreekala, C., Raghava, S.P.S., Mishra, R.L. and Voleti, S.R. 2002. Assessment of variability for carotenoides and yield components in African marigold. Journal of Ornamental Horticulture. 5(2): 5-7.

Sunitha, H.M., Ravihunje, B.S., Vyankaranahal. and Bablad, H.B. 2007. Effect of pinching and growth regulators on plant growth, flowering and seed yield in African marigold (Tagetes erecta L.). Journal of Ornamental Horticulture. 10(2): 91-95.

Tomar, B.S., Singh, B., Negi, H.C.S. and Singh, K. K. 2004. Effect of pinching on seed yield and quality traits in African marigold. Journal of Ornamental Horticulture. 7(1): 124-126. Yadav, P.K. 1997. Note on the effect of cycocel and maleic hydrazide on gowth and flowering of African marigold. Current Agriculture Research Journal. 21(2): 113-114.

\section{How to cite this article:}

Markam, P. S., Neeraj Shukla and Vikas Chandra. 2020. Influence of PGR's and Cultivars on Flower Yield and Economics of African Marigold under Chhattisgarh Plain. Int.J.Curr.Microbiol.App.Sci. 9(08): 543-549. doi: https://doi.org/10.20546/ijcmas.2020.908.061 